\title{
ランチョンセミナー(19) アレルギー疾患の治療の満足度向上のために
}

\author{
岡野 光博 \\ 国際医療福祉大学医学部 耳鼻咽喉科学
}

1. はじめに

アレルギー性鼻炎の治療満足度は決して高くない。今野らが2008年に行ったウェブ調査では、第 2 世代抗ヒスタミン 薬での治療に満足したスギ花粉症患者は約 $35 \%$ にすきない。本疾患は、発作的な症状を来すものの慢性的な経過をたど る。したがって、正確な診断を基にした、急性発作すなわち発症・症状増悪時の対応と、長期管理すなわち症状増悪を 予防する対応が本疾患の治療満足度を向上させるために重要である。

2. アレルギー性鼻炎治療のエンドポイント

アレルギー性鼻炎治療のエンドポイント（治療目標）としては、(1) 免疫学的寛解、(2) 生理学的寛解、(3) 臨床的寛 解、がある。このうち、免疫学的寛解すなわち未感作の状態に到達することは困難である。現実的なエンドポイントは 臨床的寛解、すなわち症状はあっても軽度で日常生活に支障のない状態に到達することであり、理想は生理学的寛解、 すなわち抗原誘発反応がない状態を得ることである。一方、個々の患者が望むエンドポイントはさまざまである。日常 生活に支障のない状態の維持を希望する患者もいれば、入試や会議など大切なイベント時のみ発症を抑えたい患者も存 在する。効果は弱くても副作用の少ない治療を希望する患者もおれば、逆の患者もいる。診断のみを希望して受診する 患者もいる。「医師と患者とのコミュニケーション」が治療満足度の第一歩であり、患者の希望するエンドポイントは 何か、今回の治療に何を求めるのか、丁寧にかつ要領よく問診する。

\section{3. 環境整備}

アレルギー性鼻炎は I 型のアレルギー疾患である。抗原曝露がなけれげ発症しないし、懪露抗原量が多けれげ治療効 果は減弱するため、抗原の除去・回避など環境整備に関する患者指導は治療満足度向上に必須である。通年性鼻炎の代 表的な原因アレルゲンは室内塵ダニである。ダニは $3 \sim 4$ 週で成虫になり、生涯に40～80個を産卵し、約 2,000 個の糞 を排出する。ダニアレルゲンのいくつかは消化酵素であり、粪便中のアレルゲン活性は高い。ダニ対策としては、ホコ リを舞い上げない排気循環式掃除機を用いた清掃や換気の励行、ダニが繁殖しやすい機具（ぬいぐるみや使われていな い古布団など）の除去、高密度䋊維による布団や枕のカバーなどが挙げられる。ダニは湿度 $50 \%$ 以下では繁殖不能にな るため、観葉植物の除去など除湿に努める。これは真菌アレルゲンについても同様である。またダニは夏が繁殖のピー クで、死骸となる秋に室内塵中の抗原量が増加する。ダニアレルギー患者では特に夏前にダニ除去について教育するこ とが肝要である。

ペット対策も重要である。特に最近のネコは室内で飼育されることが多く、抗原（Fel d 1）の付着した毛の浮遊性 が高いこともあり環境アレルゲンとして問題となる。ウサギもアレルギー反応を誘発しやすいとされる。ペットは家族 の一員であり、除去は困難である。最低限、寝室に入れないなどの回避指導を行う。一度ペットアレルギーになるとペ ットを飼育している間に寛解を得ることは難しい。アレルギー性鼻炎患者ではこれらの動物の飼育は避けるように勧め ている。

花粉抗原については従来から指摘されているように、各種の花粉観測システムを利用して花粉飛散量に注意し、花粉 が体や衣類さらには家屋内に入らないように工夫する。花粉症患者では、コンタクトレンズに付着した污れと瞬目によ る機械的刺激によってアレルギー性乳頭結膜炎（contact lens-related papillary conjunctivitis：CLPC）を生じうるので、 飛散期にはコンタクトレンズの装用は控える。

アレルギー性鼻炎ではプライム効果や最小持続炎症などにより、アレルゲンの特異的な過钽性のみならず抗原非特異 的な過敏性も妄進する。非特異的な刺激としては、受動喫煙や臭気、浮遊粒子状物質（黄砂や PM 2.5 など）があり、 曝露を避けるように指導する。

\section{4. 薬物療法}

鼻アレルギー診療ガイドラインを基に、患者の重症度と病型に応じて、第 2 世代抗ヒスタミン薬、鼻噴霧用ステロイ ド薬、抗ロイコトリエン薬などを単独あるいは併用する。中でも第 2 世代抗ヒスタミン薬、抗ロイコトリエン薬、鼻噴 霧用ステロイド薬が頻用される。抗ヒスタミン薬については、鼻アレルギー診療ガイドラインでその理想として、(1) 即効性があり効果が持続する、(2) 副作用が少ない、(3) 長期投与ができる、(4) 投与回数が 1 日 1 ～ 2 回でアドヒアラ ンスがよい、ことが挙げられている。最近の抗ヒスタミン薬はTmax（最高血中濃度到達時間）が 2 時間を切るものが 多く、即効性が期待できる。

薬物療法は費用がかかる。費用効果を考慮することも患者満足度に寄与する。費用効果分析の手法としては増分費用 効果比（Incremental Cost Effectiveness Ratio：ICER）が用いられることが多い。ICER は効果の評価尺度および費用算 出の設定によりアウトカムが異なるが、例えば症状スコアを効果、薬剤費を費用として鼻噴霧用ステロイド薬による初 
期療法の ICER を求めると、プラセボ療法を比較対照とした場合の長期（本格飛散 3 週前からの）初期療法の ICERは 62.5 円/スコアであるのに対し、短期（本格飛散 1 週前からの）初期療法は42.0円/スコアであった。すなわち、短期 初期療法が費用効果に優れていた。費用効果を気にする患者に対しては ICERを基にした治療法選択も考慮する。

\section{5. アレルゲン免疫療法}

従来は皮下注射で施行されていたが、安全性を考慮した経路として舌下免疫療法が普及しつつある。プラセボ治療に 対する総鼻症状スコアの改善率を指標とすると、舌下免疫療法は抗ヒスタミン薬や抗ロイコトリエン薬よりも症状改善 効果が高く鼻噴霧用ステロイド薬と同程度であることが最近示された。アレルギー性鼻炎患者の多くは複数の抗原に感 作されている。複数の抗原による舌下免疫療法も試みられている。最近の報告では、イネ科およびブタクサ花粉の 2 種 類による舌下免疫療法での安全性は単剂での治療と同等であり、重篤な局所副反応や全身副反応はみられなかった。そ の他、ダニ抗原については 5 12歳の小児鼻炎患者においても舌下免疫療法の効果が示された。近い将来、多重感作・ 発症例や小児に扔いても舌下免疫療法を導入できる可能性が高く、その旨を説明することは満足度向上に繋がるであろ う。

\section{6. 手術療法}

レーザ手術などの鼻粘膜の変性を目的とした手術、粘膜下下鼻甲介骨切除術などの鼻腔整復術、および後鼻神経切断 術などの鼻漏の改善を目的とした手術に分けることができる。特に鼻粘膜変性手術は外来で施行可能であり、頻用され る。いずれも効果の高い治療法であるが、薬物療法と同様にアレルギー体質を改善する治療法ではなく、術後も抗原除 去・回避を続けることが治療効果の維持に重要であることを説明する。侵襲のある治療法であり、術後約 2 週間はむし ろ症状が増悪する可能性も説明する。

\section{7. アドヒアランス向上}

アレルギー性鼻炎は慢性疾患であり、治療からの脱落例は少なくない。オランダでの調査では、寛解効果が期待でき る 3 年以上のアレルゲン免疫療法を完遂できた患者はわずか $18 \%$ であった。脱落例を防ぐ、すなわちアドヒアランス向 上のための工夫が必要である。アレルゲン免疫療法については継続した治療を受ける覚悟のある患者を選択する必要が ある。舌下免疫療法については局所副反応が少なからずみられるが、連用により減弱することが多い。ある程度の局所 副反応は想定の範囲内としてむやみに患者を不安にさせないように説明する。また点鼻薬については反応の場である下 鼻甲介に噴霧するようなクロスハンド法など投与手技を指導する。それぞれの治療薬の効果発現時期についても説明す ることが望ましい。特に点鼻薬については、血管収縮薬とステロイド薬では至適効果発現時期が大きく違うので、薬効 も含めた丁寧な説明が必要である。

8. おわりに

以上、アレルギー性鼻炎治療における患者満足度向上のための注意点を紹介した。その他、本セミナーでは合併する アレルギー疾患への対応や感冒時、あるいは妊娠時のケアについても説明したい。 